\title{
Expression of HLA-G in Human Cornea, an Immune-Privileged Tissue
}

\author{
Magali Le Discorde, Philippe Moreau, Patrick Sabatier, \\ Jean-Marc Legeais, and Edgardo D. Carosella
}

\begin{abstract}
Human leukocyte antigen (HLA)-G retains the capacity to modulate immune responses, favoring the establishment of tolerance in solid-tissue allotransplants. To better understand the mechanisms that promote corneal allograft survival, we investigated whether HLA-G was an immunoregulatory factor involved in corneal immunology. We therefore sought HLA-G expression in corneal tissues. Corneal transplantation consists in replacing the center of a diseased cornea with normal corneal tissue. Two corneal parts are not used in such surgery: diseased central corneal tissue and peripheral normal cornea. For this study, we used healthy corneas obtained from deceased donors and diseased corneas obtained from patients with pseudophakic bullous keratopathy or keratoconus who had undergone corneal transplantation. Immunohistochemical analysis carried out on the cryopreserved corneas showed a positive immunohistochemical staining
\end{abstract}

\section{ABBREVIATIONS}

HLA human leukocyte antigen

RT-PCR reverse transcription-polymerase chain reaction

\section{INTRODUCTION}

In the normal immune system, activated immune cells attack invading organisms to protect the body from infection and disease. However, this normal immune mechanism induces inflammatory reactions, which, minor as they may be, could damage tissues beyond repair. Thus, inflammation resulting from a normal immune response could damage the cornea, leading to impaired

From the Service de Recherches en Hémato-Immunologie, CEA-DSVDRM, Institut d'Hématologie, Hôpital Saint-Louis, Paris, France (M.L.D., P.M., E.D.C.); Banque Française des Yeux, Paris, France (P.S.); and Department of Ophthalmology, Laboratoire Biotechnologie et Oeil, Hôtel-Dieu Hospital, Université Pierre et Marie Curie, Paris, France (J.M.L.).

Address reprint requests to: Magali Le Discorde, Service de Recherches en Hémato-Immunologie, CEA, Institut d'Hématologie, Hôpital Saint-Louis, 1 Avenue Claude-Vellefaux, 75475 Paris cedex 10, France; Tel: 33-1 53.72.21.39; Fax: 33-1 48.03.19.60; E-mail: teyssier@dsvidf.cea.fr.

Received July 11, 2003; accepted August 14, 2003. with anti-HLA-G, anti-HLA-A, -B, and -C, and antiHLA class I monoclonal antibodies. Staining was obtained for keratocytes, epithelial cells, and endothelial cells from both healthy and pathologic human corneas, revealing the presence of HLA class I proteins, including HLA-G. HLA-G transcripts were detected in normal cornea by reverse transcriptase-polymerase chain reaction with a classical pattern of alternative splicing. The detection of HLA-G protein in adult corneas leads to the conclusion that this protein may contribute to the maintenance of the privileged immune status of cornea. Human Immunology 64, 1039-1044 (2003). (C) American Society for Histocompatibility and Immunogenetics, 2003. Published by Elsevier Inc.

KEYWORDS: HLA; cornea; keratoplasty; immunohistochemistry; RT-PCR

OCT optimal cutting temperature compound

vision or even blindness [1]. To prevent these tissuedamaging reactions, the immune response in cornea and others areas of the body is blocked by mechanisms intrinsic to the tissue concerned. These particular organs, which are considered to be immune-privileged sites, include ovary, testis, brain, and eye. The immunologic status of these organs could be compared with what occurs at the maternal-fetal interface during pregnancy, where immune tolerance is observed, avoiding rejection of the semiallogenic fetus [2]. Among the various mechanisms activated in trophoblast cells to establish this immune protection, nonclassical class I human leukocyte antigen (HLA) proteins play an active immunologic role [3]. HLA-G presents low polymorphism, with 15 allelic variations providing 7 different HLA-G1 proteins [4, 5]. At the transcriptional level, the primary HLA-G transcript undergoes alternative splicing, resulting in four 
membrane-bound (HLA-G1 through -G4) and three soluble (HLA-G5 through G7) isoforms, among which only HLA-G1 and HLA-G5 contain all the domains of classical HLA molecules $(\alpha 1, \alpha 2$, and $\alpha 3)$ noncovalently associated with $\beta 2$-microglobulin and a nonameric peptide.

Expression of HLA-G antigens allows cells to escape immunosurveillance. Indeed, several studies have confirmed that HLA-G expression, either at the cell membrane or by secretion of the soluble form, inhibits the lytic activity of both natural killer and antigen-specific cytotoxic T-cell effectors [6-8]. HLA-G may regulate the proinflammatory Th1/anti-inflammatory Th2 cytokine balance by shifting toward Th2 polarization [9]. Considering that HLA-G contribute to the escape of the fetus from immunologic attack by specialized maternal immune cells and the similar immune-privileged status of cornea, we hypothesized that HLA-G could be expressed in human cornea and thus contribute to the specific immune control of that tissue. The aim of this work was therefore to determine whether HLA-G protein could be detected in healthy and pathologic corneas. The two pathologies we studied are among the most common corneal diseases treated by corneal transplantation: one inflammatory (pseudophakic bullous keratopathy) and one degenerative (keratoconus). The normal human cornea we studied was obtained from postmortem donors, and the pathologic corneas came from patients presenting pseudophakic bullous keratopathy and keratoconus. Our results are the first demonstration that normal human cornea, an immune-privileged tissue, expresses the immunoregulatory molecule HLA-G, and that this expression is apparently unaltered in corneas affected in both tested pathologies: the pseudophakic bullous keratopathy, which is an inflammatory condition of the cornea, and the keratoconus, a degenerative disease.

\section{MATERIALS AND METHODS}

\section{Human Tissues}

Corneal transplant surgery involves total replacement of a patient's cornea with a donor cornea. In corneal transplantation, a round section of cornea from the donor is sewed in place of the diseased cornea. We used the peripheral part of the donor cornea, which is not grafted, as the normal control, and pathologic corneal tissues removed from diseased central corneas as pathologic tissue samples.

Ten normal human corneas were obtained from postmortem donors, and 11 pathologic corneas were obtained from patients presenting pseudophakic bullous keratopathy $(n=5)$ or keratoconus $(n=6)$, the two most common diseases for which corneal transplantation is needed [10].

\section{Antibodies}

All HLA-G isoforms were labeled using the $4 \mathrm{H} 84$ monoclonal antibody, an immunoglobulin (Ig)G1 antidenatured HLA-G heavy chain targeting an epitope located on the $\alpha 1$-domain (S. Fisher and M. McMaster); the IgG2a pan-class I monoclonal antibody W6/32, which recognizes classical or nonclassical HLA class I associated with $\beta 2$-microglogulin; the monoclonal antibody SV99-85 (S. Ferrone), and an IgG exhibiting a restricted label to classical HLA-A, -B and -C. Incubation with isotypic control IgG1 or IgG2a was used as the negative control.

\section{Immunohistochemistry}

Human corneas were encapsulated by optimal clotting temperature (OCT) compound and frozen in $5-\mu \mathrm{m}$-thick sections, fixed in acetone, and stored at $-80{ }^{\circ} \mathrm{C}$ until immunohistochemical analysis.

Expression of HLA-G and HLA class I protein were evaluated on acetone-fixed cryosections, using the UltraTech HRP Streptavidin-Biotin Universal Detection System (Immunotech, Coulter, France), according to the manufacturer's recommendations. Briefly, rehydration, washes, and antibody dilutions were done in PBSA (saponin $0.1 \%$, HEPES $0.01 \mathrm{M}$ in phosphate buffer saline). After endogenous peroxidase activity blockade, primary antibodies were added for 1 hour. Peroxidase-labeled antimouse secondary antibody was applied and revealed by the substrate-chromogen solution 3-amino-9-ethylcarbazole (AEC). Tissues were counterstained with hematoxylin. Immunohistochemistry was carried out on 10 peripheral corneas, 5 pseudophakic bullous keratopathies, and 6 keratoconus corneas.

\section{RNA Extraction and RT-PCR}

Total RNA was extracted from cornea biopsies, using RNA-NOW reagent (Biogentex Inc., Seabrook, TX, USA), according to the manufacturer's recommendations. RNA was treated with RNase-free DNase (Boehringer-Mannheim, Meylan, France) to remove contaminating chromosomal DNA. cDNA synthesis was accomplished by reverse transcription (RT) using oligo(dT) primer and M-MLV RT (Gibco-BRL, Life Technologies, Cergy Pontoise, France). The polymerase chain reaction (PCR) was run for 40 cycles at $94^{\circ} \mathrm{C}$ for 1 minute, at $57^{\circ} \mathrm{C}$ ( $\beta$-actin) or $61^{\circ} \mathrm{C}$ (HLA-G) for 1 minute, and at $72^{\circ} \mathrm{C}$ for 1 minute. The PCR product was run on a $1.5 \%$ agarose electrophoresis gel and transferred. Specificity of amplification was confirmed by subsequent hybridization with a ${ }^{32} \mathrm{P}$-labeled internal probe for 2 hour at $57^{\circ} \mathrm{C}\left(\beta\right.$-actin) or at $60^{\circ} \mathrm{C}$ (HLA-G(R)). RT-PCR were carried out using JEG-3 


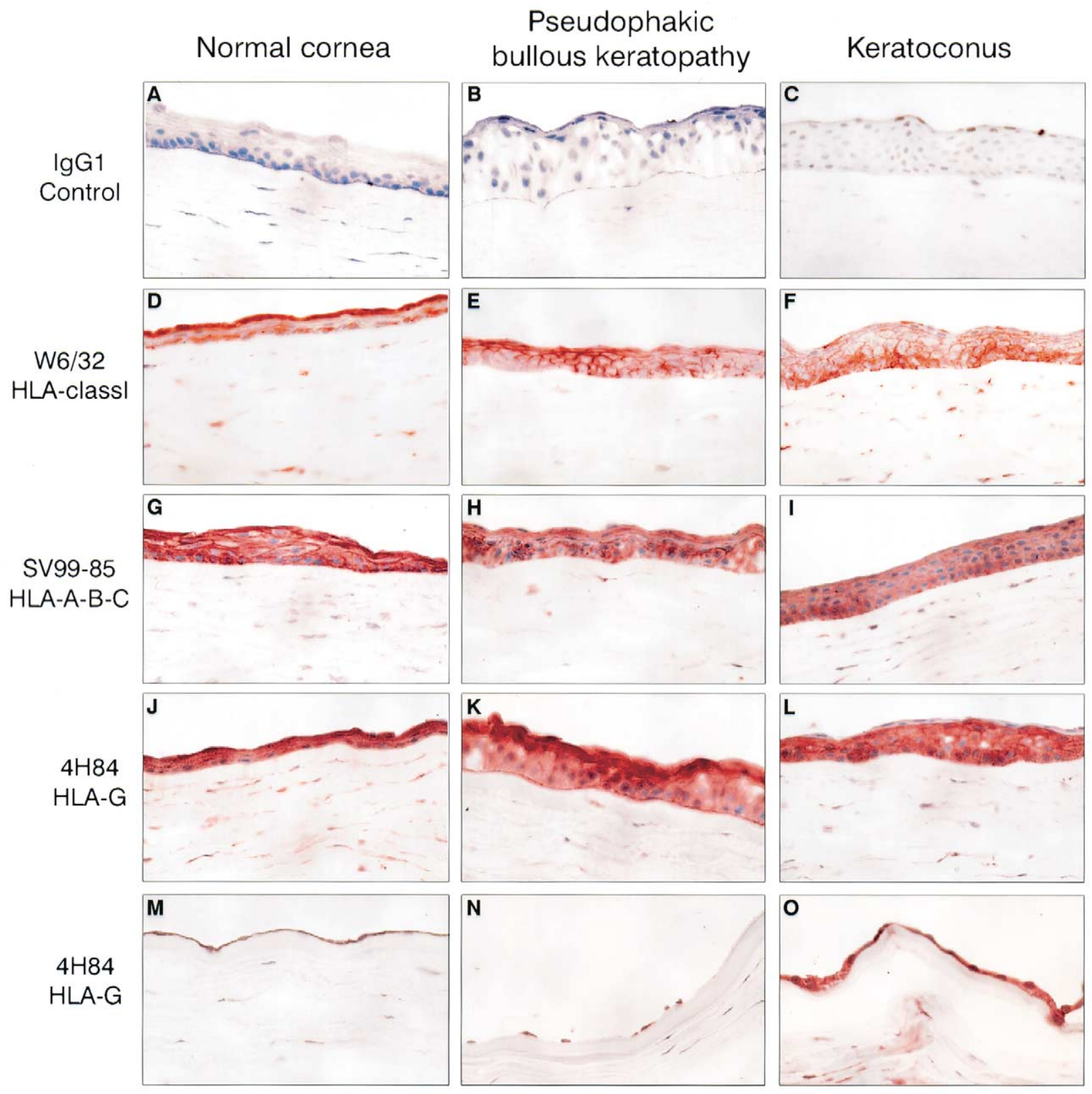

FIGURE 1 Detection of tissue antigens in normal corneas (first column), in pseudophakic bullous keratopathy (second column), and in keratoconus (third column). (A, B, C) Immunostaining with an irrelevant antibody as negative control immunoglobulin G1, (D, E, F) an anti-human leukocyte antigen (HLA) class I (W6/32), (G, H, I) an anti-HLA-A, -B, and $-\mathrm{C}$ antibody (SV99-85), and ( $\mathrm{J}$ through $\mathrm{O}$ ) an anti-HLA-G (4H84) antibody. Positive staining for HLA class I, including HLA-G, is revealed (D through $\mathrm{O}$ ) in epithelial cells, stroma, and $(\mathrm{M}, \mathrm{N}, \mathrm{O})$ endothelial cells. $\times 400$.

choriocarcinoma cells as the positive control, revealing a classical HLA-G mRNA profile expression.

\section{Oligonucleotides}

HLA-G was amplified from exon 2 by G257 forward (5' GGAAGAGGAGACACGGAACA) up to exon 5 by G1004 reverse (5'-CCTTTTCAATCTGAGCTCTTCT TT) primers (ESGS-Groupe Cybergene, Evry, France), and hybridization were achieved with an internal probe located in exon $2 \mathrm{G}(\mathrm{R})$ (5'-GGTCTGCAGGTTCATTCTGTC); $\beta$-actin transcripts were detected using a forward $\left(5^{\prime}-\right.$ ATCTGGCACCACACCTTCTACAATGAGCTGCG), a reverse (5'-CGTCATACTCCTGCTTGCTGATCCACATCTGC) primers and an internal $\beta$-actin probe $\left(5^{\prime}\right.$-ATCATGTTTGAGACCTTCAACACCCCAGCC). 


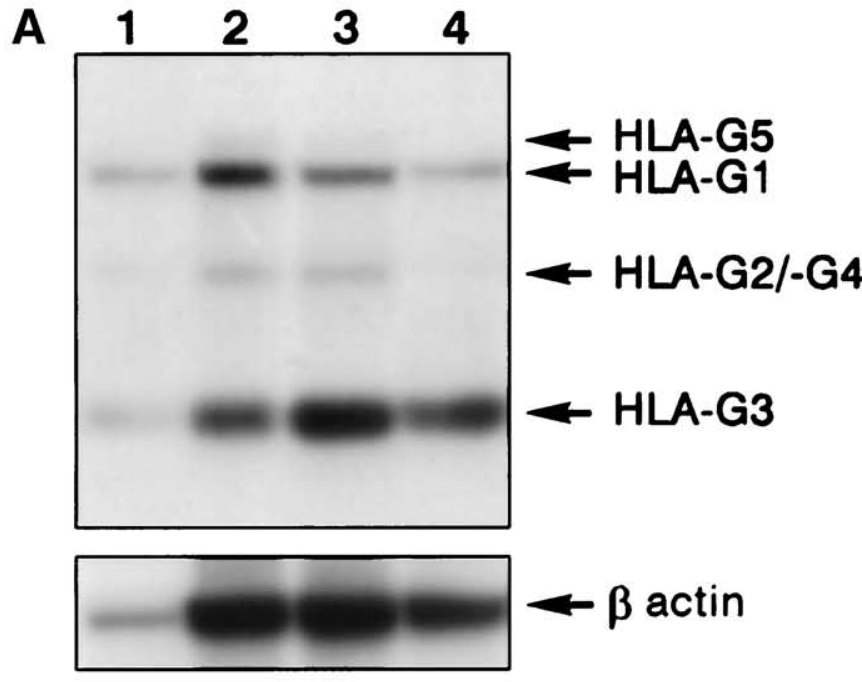

B

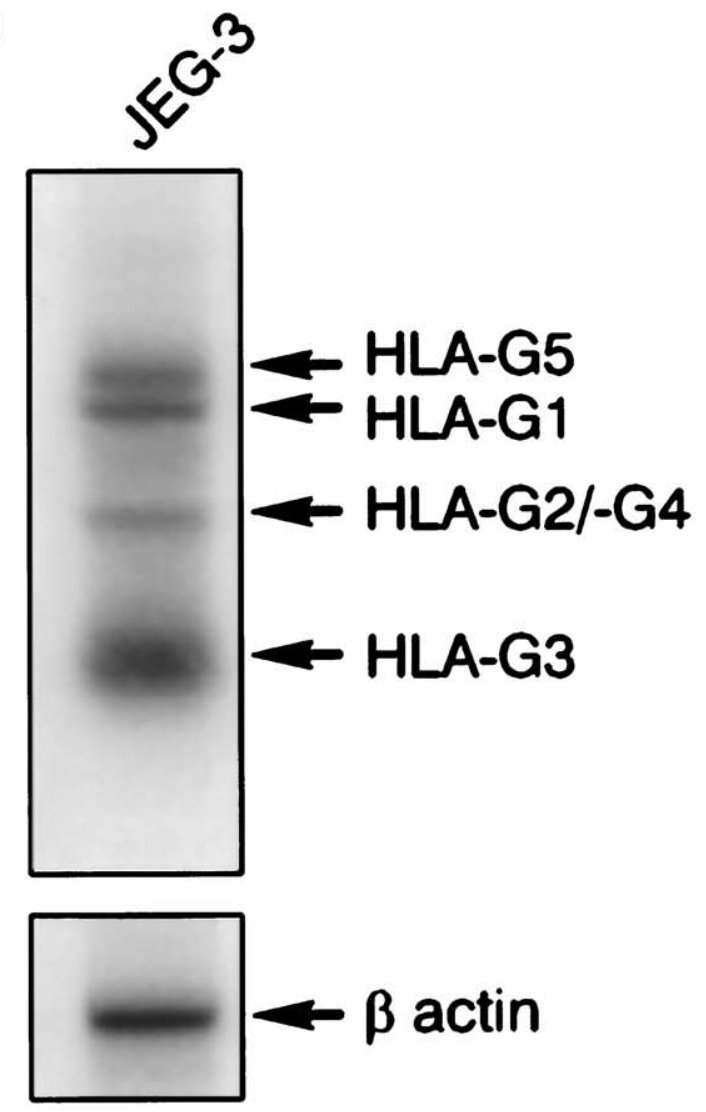

FIGURE 2 Reverse transcriptase-polymerase chain reaction (PCR) analysis of human leukocyte antigen (HLA)-G transcripts in four normal corneas (A) and in the choriocarcinoma cell line JEG-3 (B). PCR amplification was carried out using G257-G1004 primers, respectively, in exon 2 and exons 5/6. All HLA-G products are detected using the HLAG(R) probe located in exon 2. Membranar isoforms (HLA-G1 to -G4) and soluble (HLA-G5) are visualized with the same profile than in JEG-3 cells.

\section{RESULTS}

The cornea is a transparent membrane located at the most anterior portion of the eye. It is organized into three cell layers: epithelium, stroma, and endothelium. HLA-G transcripts and protein expression were found in all cell layers of normal and pathologic corneas studied.

\section{Classical and Nonclassical HLA-Class I Protein Expression in Cornea}

Normal and pseudophakic bullous keratopathy and keratoconus corneas were indirectly stained to target all HLA class I antigens, classical HLA-A, -B, and -C, and nonclassical HLA-G molecules (Figure 1, J-O). Class I antigens were detected at a high level in frozen sections from both healthy and pathologic corneas by the W6/32 antibody (Figure 1, D-F) in all cellular structures of the cornea: epithelium, keratocytes from the stromal layer, and endothelium. A similar pattern was observed with immunostaining of the classical class I HLA-A, -B, and-C antigens (SV99-85 antibody) (Figure 1, G-I). HLA-G (4H84 antibody) was detected in the epithelial layer, in keratocytes from the stroma (Figure 1, J-L), and in endothelium (Figure 1, M-O) from normal, pseudophakic bullous keratopathy, and keratoconus corneas. This staining was confirmed with the monoclonal antibody MEM-G/2 (Exbio, Prague, Czech Republic), an other anti-HLA-G proteins (data not shown).

\section{Detection of HLA-G Transcripts in Cornea}

To determine whether the HLA-G expression revealed by immunohistochemistry could derive from different isoforms, we used RT-PCR to analyze which transcripts (HLA-G1 through -G7) were expressed in normal cornea. The elastic consistency of cornea tissue rendered RNA extraction difficult. We observed the same classical pattern of HLA-G gene expression in four successive RT-PCRs, showing membranar HLA-G1 to HLA-G4, and soluble HLA-G5 transcripts (Figure 2).

\section{DISCUSSION}

In this work, we have shown that the HLA-G molecule is highly expressed in human cornea. Originally detected in chorionic cytotrophoblast cell membranes, the HLA-G molecule is expressed at the maternal-fetal interface and is involved in the protection of fetal tissues from maternal cellular immune attacks. After the immunoprotective power of HLA-G had been demonstrated [11], research focused on its role in various cell mechanisms that allow cells to escape immune surveillance, such as fetal cells escaping maternal immunity, tumor proliferation, and tolerance of transplanted organs by the host immune system.

However, few investigators analyzed HLA-G expres- 
sion in other immunologically privileged tissues, such as cornea. The immune-privileged status of organs was usually only discussed in the context of the potential of cells to use natural mechanisms to induce cell death through overexpression of the apoptotic Fas ligand [12, 13]. Present knowledge of the properties of the HLA-G molecule led us to investigate their involvement in tissues of specific immune status, in which the actions of classical immune cells are blocked to maintain the functional and structural integrity of an organ, such as in the cornea. HLA-G cDNA from a fetal human eye cDNA library suggested that HLA-G was expressed in eye tissue [14], but few articles have addressed the interesting questions raised by HLA-G expression in eye tissue. A first study, which separately investigated the anterior and posterior parts of the eye, successfully used RT-PCR to detect HLA-G transcripts in the anterior portion [15]. In addition, HLA-G protein expression has never been detected in sections of any embryonic tissues, but in 1994, a single experiment was carried out in which the antibodies used were probably not specific enough [16]. To date, only one study, using nonradioactive RT-PCR, has reported HLA-G expression in isolated human cornea at the transcriptional level, and other authors did not report such detection [17]. Publications on ocular tumors have reported negative expression of HLA-G in the Y79 retinoblastoma cell line [18], in various uveal melanoma cell lines, and in biopsies from primary uveal melanomas [19]. The interpretation of results in cell culture lines must be taken with reserve, because they cannot always be correlated with results obtained with the identical primary tumor. Indeed, cell-line culture media may be deficient in factors implicated in the maintenance of HLA-G expression that are often secreted by malignant cells, such as interleukin-10, which induces HLA-G cell-surface expression but is not found in excised tumor tissue [20-22]. In addition, induction of HLA-G protein expression after cytokine treatment of cell lines argues in favor of this point of view [23]. The absence of HLA-G protein in primary uveal melanomas was not surprising, because HLA-G has not been systematically described in melanomas [24]. Until now, HLA-G protein expression has been described as extremely restricted to fetal tissues (cytotrophoblasts, amnion epithelial cells, and chorionic villi endothelial cells) [25-27] and to adult thymic epithelial cells [28]. This very restricted tissue distribution of nonclassical HLA-G gene expression in normal physiologic situations may now be extended to normal human cornea. Phenotype analysis of HLA-G expression disclosed no difference between normal corneas and those presenting pseudophakic bullous keratopathy or keratoconus. In such a study at the phenotype level, no modulation of HLA-G protein expression in pathologic corneas could attribute a role to this protein in corneal disorders. Nevertheless, implication of HLA-G in ocular pathologies must not be excluded, in view of the fact that the distribution of HLA-G polymorphisms has already been correlated with such pathologies as preeclampsia [29].

The recent development of antibodies specific for the HLA-G1 and HLA-G5 molecules allows their detection in tissues that were found negative using previous molecular biology tools [30]. Finding HLA-G protein in adult human cornea opens the possibility of an implication of HLA-G in eye immunity. Now that we have demonstrated the presence of HLA-G in various corneal structures, it would be interesting to understand their role in the eye. The function of HLA-G in corneal tissue must be further analyzed, especially considering ophthalmologists' increased interest in the amniotic membrane (a site of known HLA-G expression) to apply it on to the ocular surface, as well as intracorneally, as a tissueengineered barrier able to protect against host immune cell infiltration [31].

ACKNOWLEDGMENTS

We are very grateful to Michèle Salvodelli and Sylvie Sousa for their technical assistance. We thank the Service Photographique de l'Institut d'Hématologie for photographic work. This study was funded by the Commissariat à l'Energie Atomique (C.E.A.). Noah Hardy edited the manuscript.

\section{REFERENCES}

1. Streilein JW, Ksander BR, Taylor AW: Immune deviation in relation to ocular immune privilege. J Immunol 158:3557, 1997.

2. Clark DA, Chaouat G: Characterization of the cellular basis for the inhibition of cytolytic effector cells by murine placenta. Cell Immunol 102:43, 1986.

3. Rouas-Freiss N, Goncalves RM, Menier C, Dausset J, Carosella ED: Direct evidence to support the role of HLA-G in protecting the fetus from maternal uterine natural killer cytolysis. Proc Natl Acad Sci U S A 94: 11520, 1997.

4. Hviid TV, Christiansen OB, Johansen JK, Hviid UR, Lundegaard C, Moller C, Morling N: Characterization of a new HLA-G allele encoding a nonconservative amino acid substitution in the alpha3 domain (exon 4) and its relevance to certain complications in pregnancy. Immunogenetics 53:48, 2001.

5. Matte C, Lacaille J, Zijenah L, Ward B, Roger M: HLA-G and HLA-E polymorphisms in an indigenous African population. Hum Immunol 61:1150, 2000.

6. Riteau B, Rouas-Freiss N, Menier C, Paul P, Dausset J, Carosella ED: HLA-G2, -G3, and -G4 isoforms expressed as nonmature cell surface glycoproteins inhibit NK and antigen-specific CTL cytolysis. J Immunol 166:5018, 2001. 
7. Le Gal FA, Riteau B, Sedlik C, Khalil-Daher I, Menier C, Dausset J, Guillet JG, Carosella ED, Rouas-Freiss N: HLA-G-mediated inhibition of antigen-specific cytotoxic T lymphocytes. Int Immunol 11:1351, 1999.

8. Bainbridge DR, Ellis SA, Sargent IL: HLA-G suppresses proliferation of CD4(+) T-lymphocytes. J Reprod Immunol 48:17, 2000

9. Rieger L, Hofmeister V, Probe C, Dietl J, Weiss EH, Steck T, Kammerer U: Th1- and Th2-like cytokine production by first trimester decidual large granular lymphocytes is influenced by HLA-G and HLA-E. Mol Hum Reprod 8:255, 2002.

10. Legeais JM, Parc C, d'Hermies F, Pouliquen Y, Renard G: Neteen years of penetrating keratoplasty in the HotelDieu Hospital in Paris. Cornea 20:603, 2001.

11. Carosella ED, Khalil-Daher I, Dausset J, Rouas-Freiss N: HLA-G mediates protection from natural killer cytolysis: implications in immune tolerance. Transplant Proc 31: 1192, 1999.

12. Kauma SW, Huff TF, Hayes N, Nilkaeo A: Placental Fas ligand expression is a mechanism for maternal immune tolerance to the fetus. J Clin Endocrinol Metab 84:2188, 1999.

13. Aoki K, Kurooka M, Chen JJ, Petryniak J, Nabel EG, Nabel GJ: Extracellular matrix interacts with soluble CD95L: retention and enhancement of cytotoxicity. Nat Immunol 2:333, 2001.

14. Shukla H, Swaroop A, Srivastava R, Weissman SM: The mRNA of a human class I gene HLA G/HLA 6.0 exhibits a restricted pattern of expression. Nucleic Acids Res 18: 2189, 1990.

15. Ishitani A, Geraghty DE: Alternative splicing of HLA-G transcripts yields proteins with primary structures resembling both class I and class II antigens. Proc Natl Acad Sci U S A 89:3947, 1992.

16. Chumbley G, King A, Gardner L, Howlett S, Holmes N, Loke YW: Generation of an antibody to HLA-G in transgenic mice and demonstration of the tissue reactivity of this antibody. J Reprod Immunol 27:173, 1994.

17. Robert PY, Lasalmonie C, Cogne M, Adenis JP, Drouet M: HLA-G and classical HLA class I transcripts in various components of the adult human eye. Eur J Immunogenet 26:2711999.

18. Polakova K, Russ G: Expression of the non-classical HLA-G antigen in tumor cell lines is extremely restricted. Neoplasma 47:342, 2000.

19. Hurks HM, Valter MM, Wilson L, Hilgert I, van den Elsen PJ, Jager MJ: Uveal melanoma: no expression of HLA-G. Invest Ophthalmol Vis Sci 42:3081, 2001.

20. Moreau P, Adrian-Cabestre F, Menier C, Guiard V, Gourand L, Dausset J, Carosella ED, Paul P: IL-10 selectively induces HLA-G expression in human trophoblasts and monocytes. Int Immunol 11:803, 1999.
21. Urosevic M, Willers J, Mueller B, Kempf W, Burg G, Dummer R: HLA-G protein up-regulation in primary cutaneous lymphomas is associated with interleukin-10 expression in large cell $\mathrm{T}$-cell lymphomas and indolent B-cell lymphomas. Blood 99:609, 2002.

22. Urosevic M, Kurrer MO, Kamarashev J, Mueller B, Weder W, Burg G, Stahel RA, Dummer R, Trojan A: Human leukocyte antigen $G$ up-regulation in lung cancer associates with high-grade histology, human leukocyte antigen class I loss and interleukin-10 production. Am J Pathol 159:817, 2001.

23. Wiendl H, Mitsdoerffer M, Hofmeister V, Wischhusen J, Bornemann A, Meyermann R, Weiss EH, Melms A, Weller M: A functional role of HLA-G expression in human gliomas: an alternative strategy of immune escape. J Immunol 168:4772, 2002.

24. Paul P, Cabestre FA, Le Gal FA, Khalil-Daher I, Le Danff C, Schmid M, Mercier S, Avril MF, Dausset J, Guillet JG, Carosella ED: Heterogeneity of HLA-G gene transcription and protein expression in malignant melanoma biopsies. Cancer Res 59:1954, 1999.

25. McMaster M, Zhou Y, Shorter S, Kapasi K, Geraghty D, Lim KH, Fisher S: HLA-G isoforms produced by placental cytotrophoblasts and found in amniotic fluid are due to unusual glycosylation. J Immunol 160:5922, 1998.

26. Houlihan JM, Biro PA, Harper HM, Jenkinson HJ, Holmes $\mathrm{CH}$ : The human amnion is a site of $\mathrm{MHC}$ class $\mathrm{Ib}$ expression: evidence for the expression of HLA-E and HLA-G. J Immunol 154:5665, 1995.

27. Blaschitz A, Lenfant F, Mallet V, Hartmann M, Bensussan A, Geraghty DE, Le Bouteiller P, Dohr G: Endothelial cells in chorionic fetal vessels of first trimester placenta express HLA-G. Eur J Immunol 27:3380, 1997.

28. Crisa L, McMaster MT, Ishii JK, Fisher SJ, Salomon DR: Identification of a thymic epithelial cell subset sharing expression of the class Ib HLA-G molecule with fetal trophoblasts. J Exp Med 186:289, 1997.

29. O’Brien M, McCarthy T, Jenkins D, Paul P, Dausset J, Carosella ED, Moreau P: Altered HLA-G transcription in pre-eclampsia is associated with allele specific inheritance: possible role of the HLA-G gene in susceptibility to the disease. Cell Mol Life Sci 58:1943, 2001.

30. Paul P, Rouas-Freiss N, Moreau P, Cabestre FA, Menier C, Khalil-Daher I, Pangault C, Onno M, Fauchet R, Martinez-Laso J, Morales P, Villena AA, Giacomini P, Natali PG, Frumento G, Ferrara GB, McMaster M, Fisher S, Schust D, Ferrone S, Dausset J, Geraghty D, Carosella ED: HLA-G, -E, -F preworkshop: tools and protocols for analysis of non-classical class I genes transcription and protein expression. Hum Immunol 61:1177, 2000.

31. Kubo M, Sonoda Y, Muramatsu R, Usui M: Immunogenicity of human amniotic membrane in experimental xenotransplantation. Invest Ophthalmol Vis Sci 42:1539, 2001. 